\title{
A Voluntary Delivery Point in Reverse Supply Chain for Waste Cooking Oil: An Action Plan for Participation of a Public-School in the State of Rio De Janeiro, Brazil
}

\author{
Luana dos Santos Ferreira ${ }^{1}$, Aldara da Silva César ${ }^{2, *(\mathbb{D})}$, Marco Antonio Conejero ${ }^{1(\mathbb{C})}$ \\ and Ricardo César da Silva Guabiroba \\ 1 Department of Business and Public Management, Fluminense Federal University, \\ Volta Redonda RJ 27213-145, Brazil; lusferreira@globo.com (L.d.S.F.); marcoac@id.uff.br (M.A.C.); \\ ricardocesar@id.uff.br (R.C.d.S.G.) \\ 2 Grupo de Análise e Sistemas Agroindustriais Agribusiness, Engineering Department, GASA, \\ Fluminense Federal University, Volta Redonda RJ 27.255-125, Brazil \\ * Correspondence: aldaracesar@id.uff.br
}

Received: 13 August 2018; Accepted: 5 October 2018; Published: 10 October 2018

\begin{abstract}
Improper disposal of waste cooking oil into sewer systems is harmful to the environment. Through the selective collection, this highly polluting residue can be handled in a less harmful way. The present study presents an action plan for a public school in the Region of Médio Paraíba Fluminense of the state of Rio de Janeiro, Brazil to serve as a voluntary delivery point in a reverse logistics chain for waste cooking oil. A case study method with semi-structured interviews was carried out with agents who are part of the chain, including the government, commercial residue generators, collectors, the biodiesel production industry, the community, and teachers and students of the public school. Even though the reverse supply chain for waste cooking oil in the region lacks structure, this study showed that the actors were interested in correctly disposing of waste cooking oil through partnerships and agreements. In addition to the environmental benefits, environmental education actions in public schools, such as the one in this study, can help raise student awareness of issues relative to citizenship and social responsibility and promote employment and income opportunities for recyclable material collector cooperatives and industries that use waste cooking oil as raw material.
\end{abstract}

Keywords: reverse logistics; used cooking oil; selective collection; school; environmental education

\section{Introduction}

The circular economy concept is a new business model focused on the management of discarded products and materials that hold promise for reducing their volume, contributing to the economy and the environment. This approach is increasingly seen as a solution to a number of challenges, such as waste generation, food waste, resource scarcity, and the sustainability of economic benefits [1].

Stahel [2] suggested that a circular economy would minimize waste by reducing the amount of waste; reusing what can be reused; recycling what cannot be reused; recovering materials or energy from what cannot be reduced, reused, or recycled. This process is becoming increasingly important as the amount of waste is growing even faster than the rate of urbanization [3]. Rathi [4] argued that rapid population growth and industrialization degrade the urban environment and place a heavy burden on natural resources, which undermines sustainable and equitable development. Inefficient 
management and disposal of solid waste is an obvious cause of environmental degradation in most developing countries.

One type of urban solid waste is waste cooking oil (WCO), which can cause environmental damage if discarded improperly [5]. It has been estimated that one liter of cooking oil pollutes 20,000 L of water, the same amount the average person consumes in about 14 years [6]. Waste cooking oil can obstruct sewage pipelines, while also retaining other solid waste. Sewage blockages increase the pressure in pipelines and can lead to sewage leakage into the soil. Furthermore, the collection of WCO can help reduce damage to wastewater treatment plants.

In Brazil, the National Solid Waste Policy (PNRS), established by Federal Law n. 12.305, on 2nd August 2010, sets forth rules for collecting, disposing of, and managing post-consumption products [7]. The PNRS is considered to be the legal framework that establishes the framework for the reduction, reuse, and recycling of food waste. It promotes a sense of sustainability management and, above all, assigns responsibilities appropriately between the public sector and waste generators about the waste generated [7]. Waste cooking oil is generated daily by households, restaurants, and the food service sector in general; however, this policy does not include WCO. The legislation that addresses the issue, Bill n. 2074 of 19th September 2007, is currently shelved [8]. It proposes that gas stations, supermarkets, companies, and other similar establishments that sell or distribute cooking oil maintain facilities designated for collection of WCO.

In Brazil, an estimated 6.5 million L of oil are collected for recycling, which is only $2.5 \%$ of what is produced [6]. This low collection rate is explained, in part, by the scarcity of collection points [9], which raises the costs of collection [10] and by lack of awareness-raising campaigns aimed at the population [11].

When recycled, WCO can be used as a raw material for several production chains, such as biodiesel, soap, animal feed, paint, asphalt, and putty [9]. According to César [12], Brazil has great potential to produce WCO biodiesel on a commercial scale.

Post-consumption reverse logistics are the reverse flow of a fraction of the by-products and materials that arise from the disposal of products after their original intended use, in order to return them to the production cycle in some way [13]. When WCO is returned to the production cycle, its life cycle does not end after the cooking process [14]. According to Zucatto [15], despite the several potential uses of WCO, no official statistics on the return rates are available.

The reverse logistics of WCO in the Region of the Médio Paraíba Fluminense (RMPF-Região do Médio Paraiba Fluminense) of the State of Rio de Janeiro, Brazil, has three distinct levels: (i) generation, (ii) intermediaries, which are the packaging, storage, collection and transportation locations or companies; (iii) destinations [16].

Waste cooking oil can present zero cost at its source since it is obtained through donations at collection points such as schools, which are voluntary delivery points (VDPs) in some communities in Brazil [17]. Environmental education is also essential in order for people to adopt a sustainable waste management model. The National Policy for Environmental Education, instituted by Law 9.795, of 27 April 1999, requires that environmental education is integrated into all levels and modalities of the education process [18].

The present study was justified by the need to address the relevant issue of developing appropriate WCO collection programs and correctly managing this highly polluting residue, while also including schools in the proposal. The following research question was formulated: How can a public school in the RMPF of the state of Rio de Janeiro, Brazil, act as a voluntary delivery point and support the development of a reverse supply chain for waste cooking oil?

The present article proposes an action plan for a public school to serve as a VDP in a WCO reverse supply chain. The authors provide a description of the reverse supply chain for WCO in the RMPF. A case study was carried out, using semi-structured interviews with agents who participate in the chain, including the government, waste generators, collectors, the biodiesel production industry, the community, and teachers and students of the school. 
This article is divided into five sections besides the introduction. The second section presents a theoretical framework an overview of WCO reverse logistics and environmental education in schools. The materials and methods are described in the third section. The fourth section presents the analysis of the results, followed by the fifth section, with final considerations.

\section{Theoretical Framework}

\subsection{WCO Reverse Logistics}

Green supply chain management is the integration of environmentally sound choices into the entire supply chain to improve the environmental and economic performance of individual links and of the chain as a whole; reducing the environmental impact [19]. Reverse logistics is the process of planning, implementing, and controlling the efficient and low-cost flow of raw materials, work in progress, finished products, and related information, from the point of consumption to the point of origin, with the goal of recovering value or achieving appropriate disposal [20].

Reverse logistics help reduce the loss of materials and products that would not normally be utilized. The process begins after the product is consumed, when companies must be prepared for the 4Rs: recovery, reconciliation, repair, and recycling [21]. Post-consumption products return to the production cycle through reuse, dismantling, and recycling [13]. Recycling, the last stage of the process, is the mechanism for WCO return and the focus of the present study.

Waste can be classified according to its purpose, as reverse solid waste or residue, and according to its origin, as urban, industrial, health services, rural, special, or differentiated. Waste can be disposed of (residue) in landfills or reused (reversed) through a series of physical or chemical treatments to manufacture new products [22]. Waste management is conducted through non-generation, reduction, reuse, recycling, treatment, and environmentally adequate final disposal and becomes the shared responsibility of the public and private sectors [23].

In Brazil, local governments are responsible for the adequate disposal of waste, while generators also have their own responsibilities [24]. Some Brazilian municipalities have already adopted the Municipal Plan of Integrated Solid Waste Management under the terms established by the National Solid Waste Policy [25].

Policies for the implementation of the selective collection can be carried out by cities and can be implemented in partnership with public or private recycling companies [22]. When implementing selective collection, the participation of cooperatives and other associations of collectors of recyclable and reusable material must be given priority due to its social impact [13].

However, the PNRS does not provide for the reverse logistics of WCO and the work depends on the capacity of the actors to coordinate among themselves. Intermediary agents such as cooperatives and self-employed collectors play an essential role in this chain [26,27].

Among the sustainable economic, social and environmental benefits of reusing WCO, Wildner and Hillig [28] highlighted the following:

1. Ensures income in lower-income areas, representing a permanent source of employment, and remuneration for the unskilled labor force.

2. Injects resources into local economies by creating jobs, collecting taxes, and developing the market.

3. Favors the development of environmental awareness and promotes responsible environmental behavior of companies and citizens.

4. Encourages the recycling of other materials.

5. Reduces the volume of waste generated and helps to solve the problem of the treatment of waste from consumption.

Returning $\mathrm{WCO}$ as a raw material involves several inter-related phases: packaging, collection, storage, and transportation to manufacturing locations [9]. Oil must be placed in $500 \mathrm{~mL}$ to $2 \mathrm{~L}$ containers in households, and in $20 \mathrm{~L}$ to $50 \mathrm{~L}$ containers in commercial establishments [9]. 
Households are small-quantity generators, while restaurants, hotels, snack bars, and other commercial establishments are large-quantity generators [29]. For both small and large generators, storage is necessary to reach the minimum economically feasible amount for the collection process [30].

The collection is carried out at large generators or voluntary delivery points, which receive WCO primarily from small-quantity generators [11]. The cost of having delivery points that are few and far apart is usually very high, sometimes making the return of WCO to the production cycle economically unfeasible [31]. Furthermore, route planning is essential to minimize the cost of transportation during collection [32].

Storage depends on the strategy of the collecting company. Some companies send the WCO directly to the recycling industry, while others store the oil until the right amounts are reached. In this case, it may undergo filtering to remove impurities from the foods to which the oil was exposed [9].

Using reverse logistics is sustainable when the total costs of packaging and transportation to manufacturing locations is lower than the value of the returned material, resulting in competitive advantages for recycling companies [9].

When used as material in new production chains, WCO can generate several products including soap and other biomaterials: printing ink, candles, crayons and playdough [33-36]. It can also be used to make biodiesel [37], with a WCO-to-biodiesel conversion rate of $98 \%$ via transesterification [38].

WCO-based biodiesel presents advantages in relation to other fuels. In comparison with conventional diesel, it does not emit sulfur compounds during combustion and is quickly biodegradable in soil and water. With regard to biodiesel made from other oils, it is profitable in terms of energic balance [39,40].

\subsection{Environmental Education in Schools}

In this context, environmental education has represented an essential awareness-raising strategy among citizens where there are no selective collection programs. Furthermore, the school environment is a formal pathway for environmental education [41].

The national policy for environmental education, through Law n. 9795/1999, Art 1, defines environmental education as the process of constructing social values, knowledge, skills, attitudes, and competencies in citizens to preserve the environment, quality of life, and sustainability [42]. As institutions that aim to shape the values and attitudes of citizens, schools can address the environmental dimension and understand its complexity and inserted cross-sectionally [41,43,44].

The policy further calls for the development and presentation of environmental education within the scope of the curricula of private and public schools. It should permeate all school relationships and activities and be developed across school subjects to reflect current issues and to encourage people to think about what type of world they want to live in. Finally, this type of education enables them to effectively carry out sustainable actions [42,45].

Among the sustainable practices that environmental education can address are an environmentally correct collection and destinations for WCO $[14,46]$. Whether destined for soap $[28,33,47]$ or biodiesel production $[11,48,49]$, WCO collection has been identified as an environmental education tool.

According to Segatto [50], environmental education has become essential in raising citizen awareness of ways to dispose of WCO and schools are promoters of this knowledge. The participation of schools in WCO collection is an instrument for fostering environmental education and sustainable actions.

Environmental education activities in and out of schools can include neighborhood campaigns, lectures on the subject, gymnastics, outdoor activities, work in student groups in schools, insertion of guidelines for sustainable practices in classes, and training of teachers on the subject [51,52]. According to Jacobi [41], the focus of these activities is seeking a holistic perspective on the relationships between people and the development of citizenship, nature, and the universe, considering that natural resources are being exhausted and that the main responsibility for their degradation lies with humans. 


\section{Materials and Methods}

This was a qualitative, applied, and descriptive study that aimed to describe the WCO reverse supply chain in the chosen region and propose an action plan that includes public schools as a voluntary delivery point. This research used the case study strategy, considering the unit of analysis of the participation of the public school as a VDP and the subunit, the reverse supply chain for WCO in the RMPF.

The case study method permits the investigation of a contemporary phenomenon in a real environment when it is not possible to clearly differentiate the phenomenon and the context; it demands the use of different sources of evidence [53].

The Region of Médio Paraíba Fluminense in the state of Rio de Janeiro, Brazil, has 871,775 inhabitants divided into 12 municipalities: Barra do Piraí, Barra Mansa, Itatiaia, Pinheiral, Piraí, Porto Real, Quatis, Resende, Rio Claro, Rio das Flores, Valença, and Volta Redonda [54] (Figure 1).

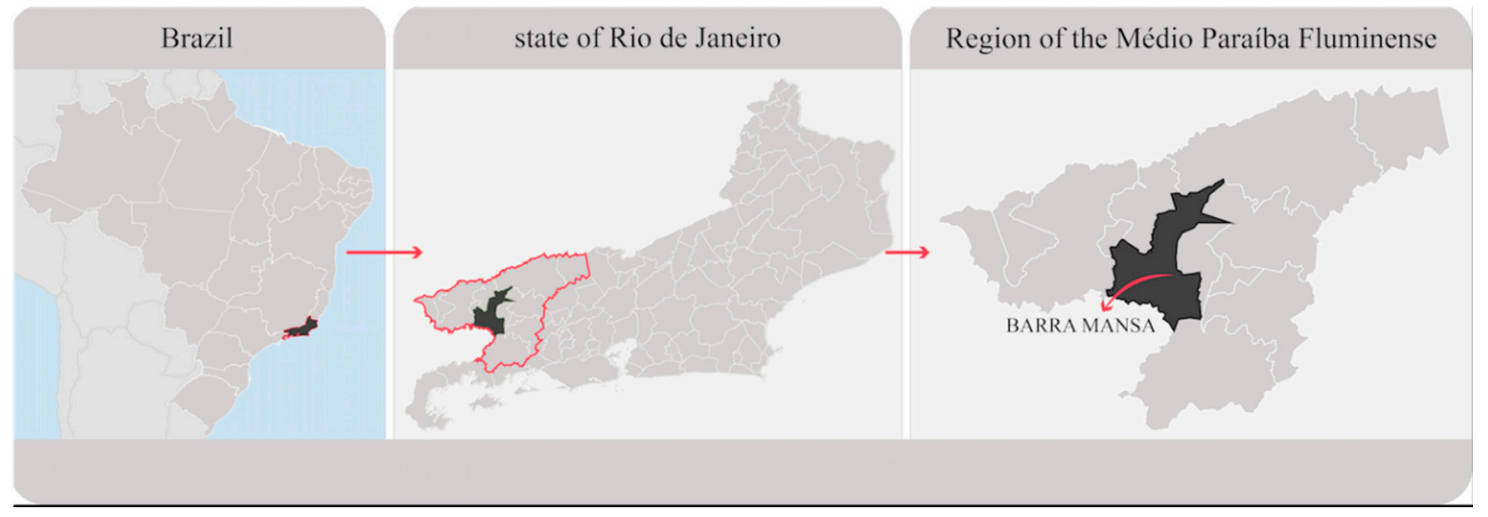

Figure 1. Maps of Brazil, the state of Rio de Janeiro, and the Region of Médio Paraíba Fluminense with emphasis on the municipality of Barra Mansa. Source: Elaborated by the authors from IBGE-Instituto Brasileiro de Geografia e Estatística (or Brazilian Institute of Geography and Statistics) [54].

The public school in question was the Washington Luiz Municipal School (CMWL-Colégio Municipal Washington Luiz), located in the municipality of Barra Mansa [55]. In March 2017, the authors conducted a document analysis by consulting the school's political-pedagogical project for 2015/2016. Internal records such as student enrollment forms and parent-teacher association (PTA) meeting protocols were also consulted to obtain information about the profile of the target audience.

The description of the reverse supply chain and development of the proposal for the school to act as a VDP in the RMPF involved the collection of primary data through on-site visits, completion of questionnaires, and interviews with the social actors involved with the issue in order to portray the current situation and propose structural and operational improvements in the operation of the system.

First, data were collected by administering a questionnaire (Appendix A) to 60 parents and guardians during PTA meetings, with the goal of assessing the community's perceptions of the topic. Under the researcher's guidance, another questionnaire (Appendix B) was administered to 50 students in the first and second stages of elementary education, between 10 and 16 years old, chosen by convenience in the classrooms. Additional data were gathered through semi-structured interviews (Appendix C) that were conducted with 8 school managers, teachers, janitorial staff, and students (Table 1). 
Table 1. Education agents interviewed in the Washington Luiz Municipal School. Source: Created by the authors.

\begin{tabular}{|c|c|c|c|c|}
\hline Educating Agent & Position & Level & Experience (Years) & Date \\
\hline EA1 & School principal & All & 14 & May/2017 \\
\hline EA2 & $\begin{array}{l}\text { Director of studies } \\
\text { Responsible for the school's } \\
\text { political-pedagogical project }\end{array}$ & All & 28 & June/2017 \\
\hline EA3 & Biology teacher & $\begin{array}{l}\text { Youth and adult } \\
\text { education }\end{array}$ & 32 & May/2017 \\
\hline EA4 & Ethics and sociology teacher & Technical & 19 & May/2017 \\
\hline EA5 & Math teacher & $\begin{array}{l}\text { Elementary } \\
\text { (year } 6 \text { to 9) }\end{array}$ & 12 & June/2017 \\
\hline EA6 & Teacher (all subjects) & $\begin{array}{l}\text { Elementary } \\
\text { (year } 1 \text { to } 5 \text { ) }\end{array}$ & 14 & June/2017 \\
\hline EA7 & $\begin{array}{l}\text { School secretary/Portuguese } \\
\text { teacher }\end{array}$ & Elementary/Technical & 26 & June/2017 \\
\hline EA8 & Janitorial staff & All & 9 & June/2017 \\
\hline
\end{tabular}

Another set of semi-structured interviews (Appendixs E and F) was carried out to obtain primary data from the 17 actors who are part of the WCO reverse supply chain in the RMPF. The public sector was represented by representatives from the municipal secretary for the environment and sustainable development and the public water and sewer treatment company. In the private sector, interviews and on-site visits were conducted with commercial generators, recycling cooperatives, associations, and companies and a representative of the local biodiesel industry. Table 2 presents the profile of all those interviewed and their corresponding organizations.

Table 2. Agents (A) interviewed from the WCO reverse supply chain in RMPF. Source: Created by the authors.

\begin{tabular}{|c|c|c|c|c|}
\hline Agent & Representation & Position & Date & Organization \\
\hline A1 & Local government & Municipal secretary & March/2017 & $\begin{array}{c}\text { Municipal Secretariat for Environment } \\
\text { and Sustainable Development } \\
\text { (SMMADS) }\end{array}$ \\
\hline $\mathrm{A} 2$ & Local government & Solid waste manager & March/2017 & SMMADS \\
\hline A3 & Local government & $\begin{array}{l}\text { Coordinator of the } \\
\text { 'Cuidando do Óleo' and } \\
\text { 'Ecopneu' projects }\end{array}$ & March/2017 & SMMADS \\
\hline A4 & $\begin{array}{c}\text { Municipal } \\
\text { autonomous body }\end{array}$ & $\begin{array}{l}\text { The engineer responsible for } \\
\text { the solid waste management }\end{array}$ & May/2017 & $\begin{array}{l}\text { Water and Sewer Treatment Service } \\
\text { (SAAE) }\end{array}$ \\
\hline A5 & Local government & $\begin{array}{l}\text { Biologist responsible for the } \\
\text { EE project }\end{array}$ & May/2017 & $\begin{array}{l}\text { Municipal Secretariat of Education } \\
\text { (SME)/Environmental Park }\end{array}$ \\
\hline A6 & $\begin{array}{l}\text { Commercial } \\
\text { generator }\end{array}$ & Nutritionist & June/2017 & Hospital restaurant \\
\hline A7 & $\begin{array}{l}\text { Commercial } \\
\text { generator }\end{array}$ & In charge of the snack sector & June/2017 & Bakery, snack bar and restaurant \\
\hline A8 & $\begin{array}{l}\text { Commercial } \\
\text { generator }\end{array}$ & Owner & June/2017 & Snack bar \\
\hline A9 & $\begin{array}{l}\text { Commercial } \\
\text { generator }\end{array}$ & President & June/2017 & $\begin{array}{l}\text { Association of Hotels, Restaurants, Bars, } \\
\text { and Others }\end{array}$ \\
\hline A10 & VDP & Manager & May/2017 & Supermarket \\
\hline A11 & VDP & Advertising assistant & May/2017 & Sesc \\
\hline A12 & Collection & $\begin{array}{l}\text { Supervisor responsible for } \\
\text { oil collection }\end{array}$ & May/2017 & Cooperative of collectors \\
\hline A13 & $\begin{array}{l}\text { WCO biodiesel } \\
\text { plant }\end{array}$ & $\begin{array}{l}\text { Engineer responsible for } \\
\text { biodiesel production }\end{array}$ & April/2017 & Biodiesel company \\
\hline A14 & State government & Superintendent & August/2017 & PROVE \\
\hline A15 & Collection & President & March/2017 & Association of collectors \\
\hline A16 & Collection & Owner & March/2017 & Company 1 \\
\hline A17 & Collection & Owner & July/2017 & Company 2 \\
\hline
\end{tabular}

Notes: $\mathrm{EE}=$ environmental education; Sesc $=$ Brazilian Social Service of Commerce; PROVE $=$ Program for the Reutilization of Vegetable Oil. 
Thus, this study carried out a total of 25 interviews with agents and applied a total of 110 questionnaires. At the same time, in order to achieve a better grasp of the reverse logistics of WCO in the RMPF, the authors conducted a document analysis of materials from official organizations and websites.

Finally, data analysis was conducted by triangulating the data obtained from the literature, document analysis, questionnaires, and interviews [56].

\section{Analysis of Results}

\subsection{The Reverse Supply Chain for WCO in the RMPF}

Based on the document analysis and interviews, the authors were able to describe the generation, intermediary (collection and transportation), and destination phases of the WCO reverse supply chain in the RMPF, as shown in Figure 2.

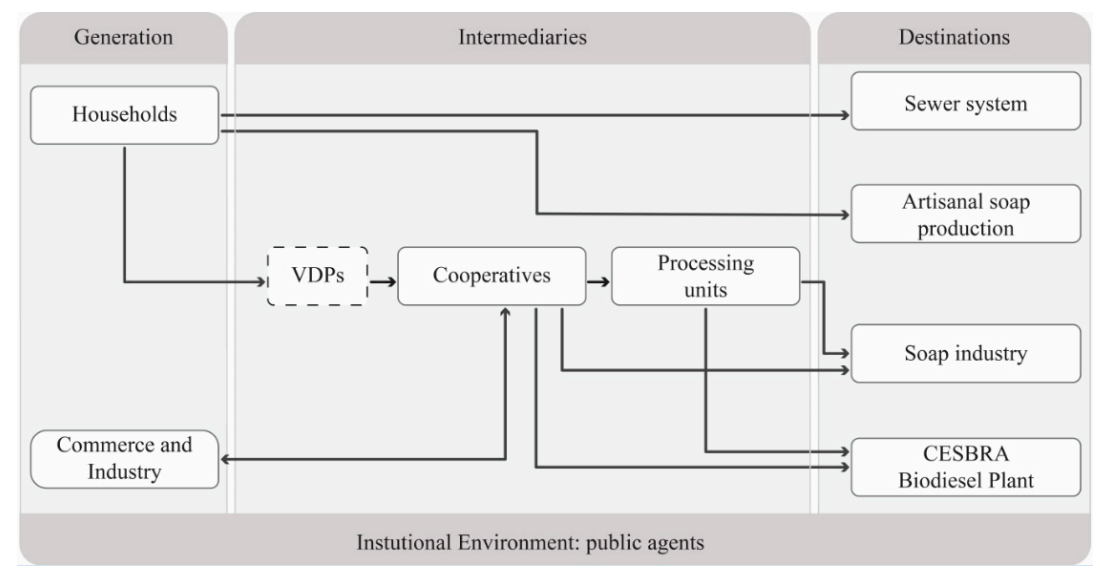

Figure 2. Waste Cooking Oil reverse supply chain in the Region of Médio Paraíba Fluminense.

\subsubsection{Generation Phase}

Residential generators can dispose of WCO directly in the sewer system, reutilize it in artisanal soap production, or deliver it to VDPs. Waste cooking oil delivered to VDPs is usually stored in plastic PET (Polyethylene Terephthalate) bottles. According to one of the representatives of a WCO collector (A15), households and commercial establishments should separate WCO from food material particles by filtering it before packaging, but this is not usually done.

For generators in commercial establishments and industry, WCO is collected at bars, restaurants, bakeries, snack bars, and institutions (schools, churches, local government) in barrels that are later collected by cooperatives. However, the president of the Association of Hotels, Restaurants, Bars, and Others (A9) pointed out that there is no policy or inspection regarding the correct disposal of WCO generated in the region by commercial generators. Even though the association provides guidance in their meetings about the treatment and final disposal of waste, the association itself is unaware of the correct disposal of WCO.

For example, participant A7, who delivers WCO to the collection company in exchange for cleaning supplies, said he had never bothered to learn about the WCO's final destination. The nutritionist (A6) also emphasized that the generators are not always informed of the destination for the WCO.

According to participant A8, the average amount of vegetable oil used per month varies greatly because people tend to eat more fried foods when the weather is cold. Even with the advent of recent innovations such as electric fryers, the most common technique is immersion frying in a pot or saucepan. This participant also reported that the volume of WCO waste was approximately two-thirds of the oil used for frying because the other third is absorbed into the food. 
As mentioned by participant A6, the standards set by the Brazilian Health Regulatory Agency do not allow for the utilization of used oil. The reason is that if it has been used for a long period, the oil generates compounds responsible for unpleasant odors and tastes, including substances that can cause health hazards to consumers, such as gastrointestinal tract irritation and diarrhea.

The Rio de Janeiro State Plan showed that the average generation of urban solid waste in the RMPF was $0.81 \mathrm{~kg} /$ capita/day in 2014 [57]. There are no statistics about the amount of WCO generated in the RMPF. However, according to the experience of participants A6 and A9, the average consumption in the region is about $1.5 \mathrm{~L} /$ capita/month. Considering that two-thirds of this amount is disposed of and that there are 800,000 inhabitants in the region (excluding $10 \%$ of the population that does not consume fried foods), the total monthly average amount of WCO generated in the RMPF can be estimated at $800,000 \mathrm{~L}$.

All of the participants in the generation phase expressed optimism regarding the growth and structuring of the WCO reverse supply chain and pointed to awareness-raising as one of the key points in this process. According to participants A2 and A3, awareness-raising actions in schools could help with WCO collection initiatives, since children and adolescents tend to influence their parents' attitudes and contribute to behavioral changes in the whole family.

\subsubsection{Intermediary Phase}

In the intermediary phase, represented by VDPs, companies, cooperatives and processing units, WCO is collected and transported directly from the generators or VDPs to recycling warehouses owned by companies or associations/cooperatives. Table 3 presents the profile of the organizations involved in WCO collection and the municipalities involved.

Table 3. WCO collection organizations in the Region of Médio Paraíba Fluminense. Source: Created based on data from IBGE [54] and field research.

\begin{tabular}{|c|c|c|}
\hline Organization & $\begin{array}{l}\text { Municipalities Where the Company } \\
\text { Operates and an Estimated Population }\end{array}$ & Description \\
\hline \multirow{6}{*}{$\begin{array}{l}\text { Óleo Local } \\
\text { (company) }\end{array}$} & Barra do Piraí-96,261 & \multirow{6}{*}{$\begin{array}{l}\text { - Founded in } 2010 \text { in Barra do Piraí } \\
\text { - } \quad \text { WCO collection of approximately } 40,000 \mathrm{~L} / \mathrm{month} \\
\text { - } \quad \text { Supported by UNIMED (a health insurance } \\
\text { company) as a VDP } \\
\text { - In } 2017 \text {, the company reached } 60 \text { collection points } \\
\text { and } 560 \text { registered commercial establishments }\end{array}$} \\
\hline & Valença-73,154 & \\
\hline & Rio das Flores-8783 & \\
\hline & Volta Redonda-261.522 & \\
\hline & Barra Mansa-179,472 & \\
\hline & Piraí-27,311 & \\
\hline \multirow{5}{*}{$\begin{array}{c}\text { Ecoleta } \\
\text { (company) }\end{array}$} & Resende-123,385 & \multirow{5}{*}{$\begin{array}{l}\text { - Founded in } 2007 \text { in Resende } \\
\text { - WCO collection of approximately 50,000 L/month } \\
\text { - Partnered with the Retailer's Steering Committee } \\
\text { of Resende } \\
\text { - Has } 150 \text { collection points and carries out } \\
\text { awareness-raising actions in schools }\end{array}$} \\
\hline & Itatiaia-29,744 & \\
\hline & Quatis-13,283 & \\
\hline & Porto Real-17,663 & \\
\hline & Barra Mansa-179,472 & \\
\hline \multirow{3}{*}{$\begin{array}{l}\text { Cicloóleo } \\
\text { (company) }\end{array}$} & Volta Redonda-261,522 & \multirow{3}{*}{$\begin{array}{l}\text { - } \quad \text { Private company located in Volta Redonda } \\
\text { - } \quad \text { WCO collection of approximately } 45,000 \mathrm{~L} / \mathrm{month} \\
\text { - } \quad \text { All WCO destined for biodiesel production }\end{array}$} \\
\hline & Pinheiral-23,488 & \\
\hline & Porto Real-17,663 & \\
\hline $\begin{array}{c}\text { Ecoóleo } \\
\text { (association) }\end{array}$ & Volta Redonda-261,522 & $\begin{array}{l}\text { - } \quad \text { Liquid and Solid Waste CollectorsAssociation } \\
\text { - } \quad \text { Founded in } 2007 \text { in Volta Redonda } \\
\text { - } \\
\text { - }\end{array}$ \\
\hline $\begin{array}{c}\text { Coopcat } \\
\text { (cooperative) }\end{array}$ & Barra Mansa-179,472 & $\begin{array}{l}\text { - Collector's cooperative of Barra Mansa } \\
\text { - Founded in } 2013 \\
\text { - Part of the local government's "Cuidando do Óleo" } \\
\text { project, in partnership with the State Institute for } \\
\text { the Environment (INEA) and the State Program for } \\
\text { the Reutilization of Vegetable Oil (PROVE); } \\
\text { - WCO collection of approximately } 3100 \mathrm{~L} / \mathrm{month}\end{array}$ \\
\hline
\end{tabular}


The RMPF associations/cooperatives are supported by the Program for the Reutilization of Vegetable Oil (PROVE) of the State of Rio de Janeiro. According to participant A14, PROVE promotes partnerships between public agents, the third sector, companies, and representative groups. In addition to fostering the organization of collectors into cooperatives, it also provides vehicles for collection, supporting the reverse logistics of various types of waste.

Partnerships with commercial generators are trust-based. Participants A2 and A3 stated that WCO collection actions are still very informal and need to be formalized through agreements or contracts. The commercial generators registered by the cooperatives or private companies receive barrels to dispose of the WCO. When the barrels are full, the generators call the cooperatives and the full barrels are exchanged for empty ones. However, participant A7 pointed out that delays in the collection make the WCO start to release unpleasant odors in the establishments.

Participant A15 also emphasized the variability in the supply of commercial generators, which hinders collection logistics. According to him, the amount collected ranges from $100 \mathrm{~L}$ to $200 \mathrm{~L}$ per partner; in a month; this represents a 50\% variation, ranging anywhere from 8000 to $12,000 \mathrm{~L}$.

To encourage these partnerships, A15 suggested that commercial generators "receive cleaning materials in exchange. Chlorine is produced by cooperatives as an incentive for cooperation." In addition, enterprises/cooperatives provide green seals as a form of recognition. According to this participant, in the case of his cooperative, the seal is awarded by the Secretary of the Environment of the Volta Redonda municipality. In the case of another cooperative, according to participant A12, commercial generators are awarded a PROVE Seal for adequate WCO disposal that is valid for one year. In the case of companies, they provide their own green seals, as stated by participants A16 and A17.

However, the Secretary of the Environment and Sustainable Development of the Barra Mansa municipality does not support the exchange of WCO for cleaning products. According to A3, that is because the soap produced by the collector organizations generally does not meet technical specifications and can also harm human health and the environment.

It is also important to consider the financial incentives provided by some companies/cooperatives in exchange for WCO provided by residential and commercial generators. According to participant $\mathrm{A} 1$, in the near future, it will become difficult for cooperatives to obtain donations because WCO has become profitable waste. Companies and cooperatives pay between 0.80 and 1.00 Brazilian reais/L of WCO. The percentage of WCO lost and WCO sold after filtering is minimal. Sales are not just to biodiesel industries and their destination is uncertain. Nonetheless, WCO is sold for an average of 1.40 to 1.80 Brazilian reais/L. However, when soy harvests are good, and the price of vegetable oil is low, the value paid per L of WCO ranges between 1.20 and 1.30 Brazilian reais.

One of the challenges in the collection phase mentioned by the participants responsible for the collector companies and cooperatives was competition with self-employed informal collectors, who pay more per L to establish that the collection points are theirs. Another barrier to the residential collection is that even though people are aware of the possible damage caused by disposing of WCO down the sink, most do so because it is easier. Furthermore, the collector companies and cooperatives must also compete with homemade soap production.

The cooperatives and companies licensed to treat WCO generate monthly reports to government organizations that include information about the amount of WCO collected per registered commercial generator. These reports allow the local government to control the adequate disposal of this waste.

Storage and transportation require certain precautions to avoid WCO leaks; the barrels are placed on top of pallets covered with cardboard. Filtering of WCO can be performed at the collector cooperatives, or it can be sent to other processing units before being sent to biodiesel companies or the soap industry. In company or cooperative warehouses, the WCO is sieved to eliminate food particles and it decants for $24 \mathrm{~h}$ to separate the water from the oil. After this period, a sample is collected and tested; it should contain less than $1 \%$ of water before being approved for sale. 
The intermediary links of the chain also foster awareness regarding WCO collection. Companies and cooperatives work with schools (municipal, state and private), providing students, staff, and teachers with information through lectures, posters, and pamphlets to encourage WCO collection and re-utilization in soap production and alternative sources of energy, such as biodiesel.

In some municipalities, schools already function as VDPs. According to participants A3 and A16, the "Cuidando do óleo" project, a partnership of the municipality of Barra Mansa with a cooperative, and the "Viva Óleo" project of a company in the city of Resende, held rallies at all public and private schools before they became VDPs. However, according to participants A12 and A16, these projects were canceled because of a lack of government support.

As stated by participant A17, working with households is a greater challenge. When residences are part of the collection route, they can be fit in according to market demand. He said, "It's no use saying that you're solving an environmental problem, generating $70 \%$ less polluting fuel if you're riding around in your car with no efficiency. We need to optimize and improve our relationship with generators."

One of the municipality representatives interviewed in this study (A1) emphasized the inefficiency of the residential collection strategy. According to this participant, "Housewives are not in the habit of requesting collection service by phone. They may even separate the WCO but they don't call us to collect it. So, it all gets thrown away together with the other residential trash." Participant A12 indicated that one solution to the problem of residential collection would be raising awareness through environmental education so that WCO generated in households gets delivered to VDPs.

\subsubsection{Destination Phase}

The most common destination of WCO is the sewer system, followed by artisanal soap production, and the soap and biodiesel industries.

According to participants A3 and A5, it is a common practice to reutilize WCO in artisanal soap production in the RMPF. Community members generate income by selling these products and churches offer soap-making courses for job and income generation. As voiced by participant A1, the greatest problem in the production of homemade soap is lack of environmental control and precautions in the manufacturing process. This participant said, "caustic soda, which is used as the reagent, can burn the person manufacturing the soap."

In Brazil, approximately 30 million L of WCO is used to produce biodiesel [58]. In the RMPF there are two biodiesel companies: CESBRA and OLFAR. However, up to the time of this study, OLFAR had not begun operations using WCO as a raw material in biodiesel production. Participant A13 indicated that the nominal production capacity of the CESBRA biodiesel plant, as authorized by the National Agency of Petroleum, Natural Gas and Biofuels, is $10,000 \mathrm{~m}^{3}$ per bimester, for a total of $60,000 \mathrm{~m}^{3}$ per year. Currently, the plant produces $4000 \mathrm{~m}^{3}$ per bimester, $40 \%$ of the authorized capacity.

Biodiesel production uses degummed soybean and palm oils and several other raw materials, depending on the oilseed harvest. Regionally, WCO corresponds to $40 \%$ of the raw material used to produce biodiesel. According to participant A13, the low supply of WCO increased the value per L from 0.50 to 2.50 Brazilian reais in 2016. The amount paid for WCO is associated with the soybean harvest: "The price fluctuates according to the price of the main raw material but it is a competitive value. The last batch cost approximately 1.50 Brazilian reais/L."

Participant A13 also noted that the biodiesel industry faces some competition from the soap industry but mainly competes with some rendering and tallow companies to obtain WCO. Soap companies such as Grande Rio, Mauá, and 3Brio are not significant competitors. The JBS industry, located in Lins, São Paulo, produces approximately $20,000 \mathrm{~m}^{3}$ of biodiesel per bimester and for participant $\mathrm{A} 13$, it can be considered their biggest competitor for purchasing WCO.

There are 24 specifications for biodiesel to be sold at auctions. According to participant A13, the main quality indexes are solid impurities, acidity, and amount of water in the WCO. When it is treated, WCO is heated, breaking the emulsion. The oil sinks to the bottom of the container, from 
which oil, flour, and all other impurities are drained. For biodiesel production, the maximum acidity is $3 \%$. If it does not meet this target, this residue is mixed with caustic soda, a catalyst, and used to produce soap instead of biodiesel. Regarding the water content, the maximum acceptable level for biodiesel production is $0.02 \%$. As the WCO arrives with over $1 \%$ of water, it must undergo a $12 \mathrm{~h}$ drying process at $150^{\circ} \mathrm{C}$ in a vacuum chamber.

Regarding the yield, participant A13 estimated that $1 \mathrm{~kg}$ of WCO produces $990 \mathrm{~g}$ of biodiesel. This means that $1 \%$ of the material is lost, which is better than the $4 \%$ loss with soybeans. The biodiesel industry plans to expand its biodiesel production with $\mathrm{WCO}$, based on expected growth and increasing professionalization of the WCO market.

\subsubsection{Institutional Environment: Public Agents in the RMPF}

The public agents interviewed in the Barra Mansa municipality represented the Municipal Secretary for the Environment and Sustainable Development (SMMADS) and the Public Water and Sewer Treatment Service (SAAE).

Participant A2 stated that the SMMADS intends to resume their environmental education activities so that municipal schools can function as VDPs; however, he indicated that no such activities have been planned yet. Participant A1 emphasized the need to resume awareness-raising and environmental education programs: "The local government does not depend on its own resources for collection programs because the Rio de Janeiro State Secretariat of the Environment provides this support. The program lacks continuity and greater adherence by the population."

It is worth noting that there was a high turnover in the persons responsible for the municipal secretariats in the RMPF during the data collection period. The same was true for the management involved in the WCO collection programs.

According to participant A4, who is with the SAAE, accumulation of oil and grease in the pipe system can cause blockages and sewer backups, and can even break the pipes that are part of the wastewater collection system. Toxic chemicals are used to remove this material and unclog pipes, creating a vicious cycle, which can even lead to significant increases in the costs of water and sewer services. However, the SAAE has no statistics available regarding the costs involved and the reasons for sewer blockages.

Although public agents are mobilizing actors to participate in WCO selective collection programs in RMPF municipalities, the application of economic instruments such as fiscal and tax incentives and the creation of more specific laws could accelerate the process and increase the volume of WCO collected to produce biodiesel.

\subsection{The Washington Luiz Public School as a Voluntary Delivery Point for WCO in the RMPF}

\subsubsection{Educating Agents}

According to participants AE1 and AE2, environmental education programs are usually proposed through partnerships between municipal government organizations in Barra Mansa that involve the Secretary of Education, the Secretary of the Environment and the SAAE. Environmental education initiatives in the school curriculum always depend on the support of external agents, i.e., partners from private institutions.

All of the participants expressed their support for an environmental education project involving WCO and the participation of schools as VDPs. For them, a permanent WCO collection program at Washington Luiz Public School (CMWL), supported by the Secretary of the Environment and other public organizations, would be of great importance in promoting environmental education and student awareness of sustainable development.

The school management expressed interest in including a recycling project and other environmental initiatives in the political-pedagogical project. However, the teachers were more skeptical, based on the discontinuity that occurred with previous programs. 
According to the director of studies of the CMWL (AE2), there have previously been projects in which WCO was collected and delivered to a collector company that was a partner of the Municipal Secretary of Education. At the end of the year, the participating schools were ranked, and the schools with the highest rankings won prizes.

However, all agreed that, in addition to such actions, it is necessary to make the insertion of environmental education in the school curriculum and political-pedagogical project official. According to those interviewed, addressing the topic in specific subjects or extracurricular activities is not enough to awaken student interest and ensure their actual participation in actions directed at social-environmental issues.

\subsubsection{Students}

The students' views regarding environmental education were associated with preservation of the environment. All the students had had some experience with environmental education. Chart 1 presents the motivational factors regarding student participation in WCO collection programs. Thirty-six percent of the students justified their lack of interest in WCO collection activities by saying that they had not received the prizes that had been promised to them. They also said that some teachers do not release them from class to participate in these types of activities.

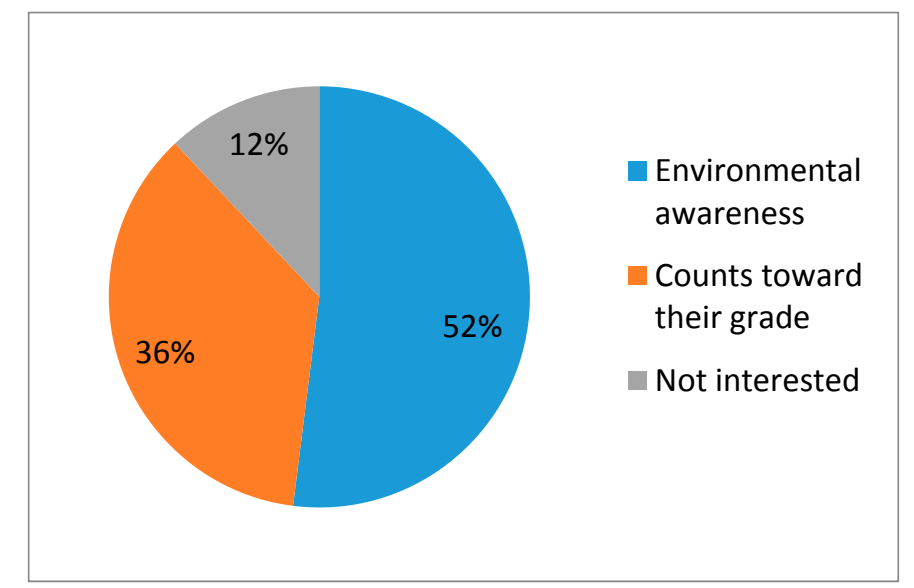

Chart 1. Motivational factors for student participation in WCO collection programs. Source: Created by the authors based on field research.

Chart 2 presents the destinations of WCO in the students' households. The most common destinations were soap production and separation for selective door-to-door collection.

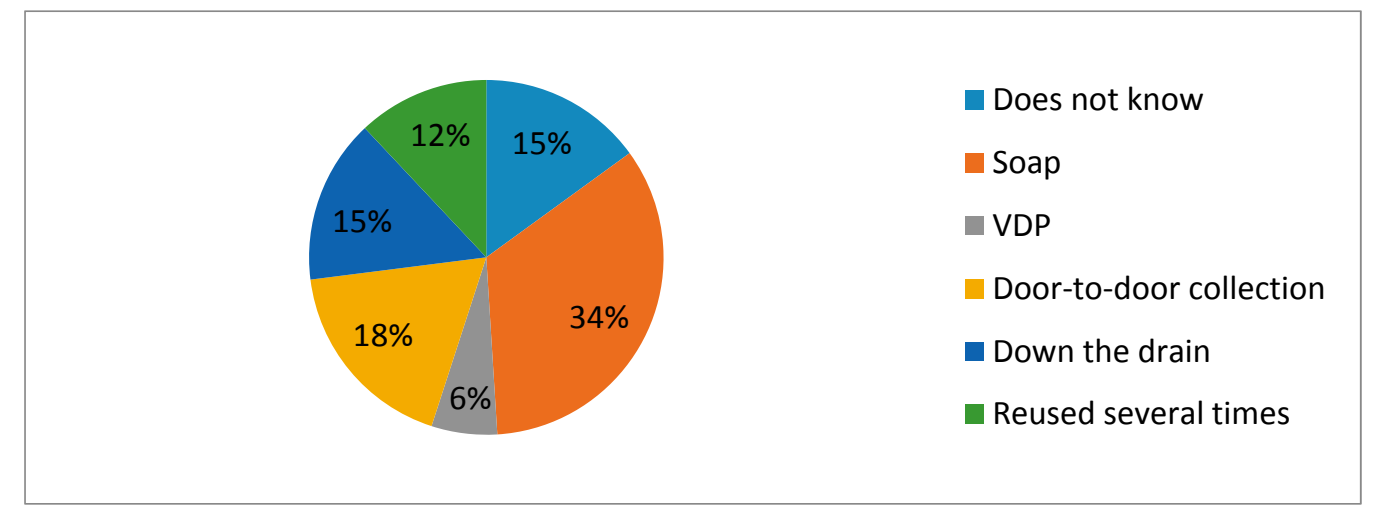

Chart 2. Destinations of WCO in students' households. Source: Created by the authors based on field research. 


\subsubsection{The Community}

The questionnaires given to community members revealed that $23 \%$ of the participants had not finished elementary school, 34\% had completed elementary school, $40 \%$ had finished high school, and another $3 \%$ had a university degree. On average, four people lived in the households of those interviewed. The monthly household income was between one and two monthly minimum wages in two-thirds of the families. Only three families received social welfare from the Bolsa Família program. Half of the participants were not aware of the meaning of environmental education. It is worth noting that in Brazil the designations of the social classes are based on the number of minimum wages (MW). In 2018, the MW was 952 Brazilian reais, and, five classes are defined: A (more than $20 \mathrm{MW}$ ); B (from 10 to $20 \mathrm{MW}$ ); C (from 4 to $10 \mathrm{MW}$ ); D (from 2 to $4 \mathrm{MW}$ ); and $\mathrm{E}$ (up to $2 \mathrm{MW}$ ).

The present study found that the mean consumption of vegetable oil was $1.4 \mathrm{~L} / \mathrm{month} /$ per capita. This is below the national average of $1.6 \mathrm{~L}$ in 2015 [2]. All the participants reused the oil at least once before disposing of it. Regarding the destinations of the WCO, as seen in Chart 3, the main options were a donation, soap production, and pouring it down the drain. Those who poured the oil down the drain were aware of the potential for environmental damage.

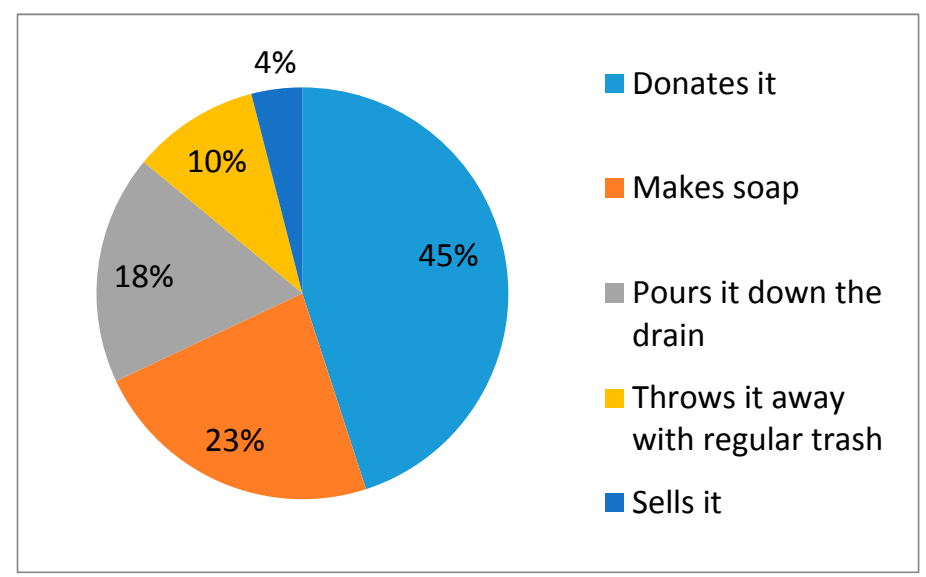

Chart 3. Destinations of WCO in the community. Source: Created by the authors based on field research.

Regarding donations, Chart 4 illustrates the competition between collection companies/ cooperatives and the soap industry to obtain residential WCO. Regarding the utility of WCO, only one-third of those interviewed knew the purposes of WCO as a raw material. Only two participants mentioned soap production in schools and churches. None of the participants knew that WCO could be used in biodiesel production.

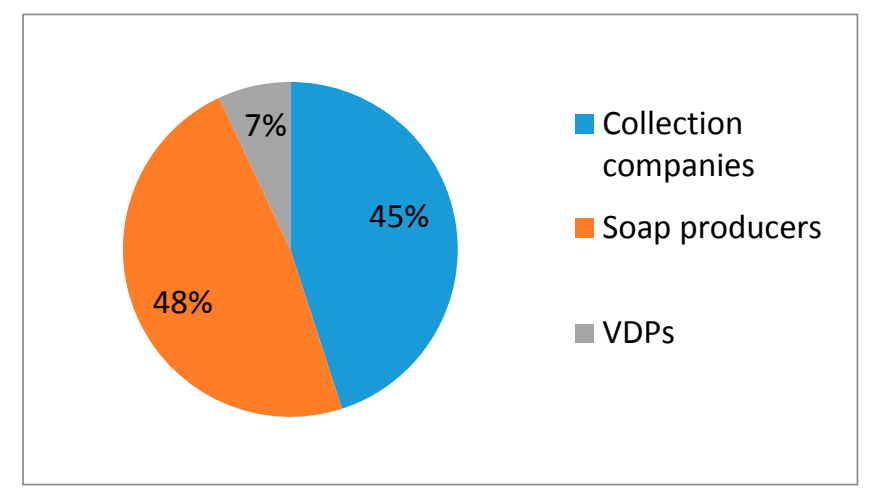

Chart 4. Destinations of community WCO donations. Source: Created by the authors based on field research. 
Chart 5 shows that, among the main barriers mentioned by the community to delivering WCO to VDPs, those most cited were lack of time, distance, or being unaware of VDPs in the municipality. In general, schools represent strategic locations and can act as VDPs and facilitate access by the population.



Chart 5. Difficulties cited by the community in delivering Waste Cooking Oil to Voluntary Delivery Points. Source: Created by the authors based on field research.

\subsection{Action Plan for Inserting the CMWL in the WCO Reverse Supply Chain in the RMPF}

Before creating an action plan for the WCO collection, it is important to involve all of the concerned actors in drafting and monitoring the school's political-pedagogical project. This is an opportunity for management, coordinators, teachers, and the community to define the profile of children's education, organizing actions to reach the proposed objectives. In this context, environmental education takes on a strategic role.

Furthermore, for the CMWL to operate as an agent of WCO reverse supply chain in the RMPF, the collaboration of other agents is essential, such as: public institutions (local governments, municipal secretariats, SAAE), commercial generators, recycling companies, associations and cooperatives, and the industries that produce biodiesel using this raw material.

Considering that a WCO reverse supply chain already exists in the RMPF, even with some bottlenecks and limitations, the action plan outlined in Table 4 describes only the internal aspects of the WCO collection operation in the school. The action plan was based on the 5W2H method, which consists of an action plan for preestablished activities that need to be as well-defined as possible. The $5 \mathrm{~W}$ represents what (what will be done?); who (who will do it?); where (where will it be done?); when (when will it be done?); why (why will it be done?). The $2 \mathrm{H}$ is: how (how will it be done?); and how much (what will it cost?) [59]. 
Table 4. An Action plan for inserting the Washington Luiz Municipal School in the WCO reverse supply chain. Source: Created by the authors.

\begin{tabular}{|c|c|c|c|c|c|c|}
\hline Who? & What? & When? & Where & Why & How & How Much? ${ }^{1}$ \\
\hline School management & $\begin{array}{l}\text { Request support from the } \\
\text { Secretariat of the Education } \\
\text { (SME) }\end{array}$ & $\begin{array}{l}\text { During the project's } \\
\text { creation phase and } \\
\text { later during the } \\
\text { school year }\end{array}$ & SME & $\begin{array}{l}\text { Evaluate and follow up } \\
\text { with the school/VD Pro } \\
\text { monitor and correct } \\
\text { possible flaws }\end{array}$ & $\begin{array}{l}\text { Memo requesting } \\
\text { support for the project }\end{array}$ & - \\
\hline School management & $\begin{array}{l}\text { Request support from the } \\
\text { Municipal Secretariat of the } \\
\text { Environment and } \\
\text { Sustainable Development } \\
\text { (SMMADS) }\end{array}$ & $\begin{array}{l}\text { Throughout the entire } \\
\text { school year }\end{array}$ & SMMADS & $\begin{array}{l}\text { Supply PET plastic } \\
\text { containers }\end{array}$ & $\begin{array}{l}\text { Memo requesting } \\
\text { support for the project }\end{array}$ & $\begin{array}{l}400 \text { Brazilian reais for } \\
\text { a container of } 100 \text { liter }\end{array}$ \\
\hline School management & $\begin{array}{l}\text { Request support from the } \\
\text { Water and Sewer Treatment } \\
\text { Service (SAAE) }\end{array}$ & $\begin{array}{l}\text { At the start of the } \\
\text { project and through } \\
\text { a request }\end{array}$ & SAAE & Awareness-raising lectures & $\begin{array}{l}\text { Letter with a partnership } \\
\text { proposal }\end{array}$ & - \\
\hline School management & $\begin{array}{l}\text { Include the school's WCO } \\
\text { VDP project in its } \\
\text { political-pedagogical } \\
\text { project }\end{array}$ & $\begin{array}{l}\text { Throughout the } \\
\text { school year }\end{array}$ & $\begin{array}{c}\text { Political-pedagogical } \\
\text { project }\end{array}$ & Document the project & $\begin{array}{l}\text { A project that includes } \\
\text { WCO collection in the } \\
\text { school through EE }\end{array}$ & - \\
\hline School management & $\begin{array}{l}\text { Creating informational } \\
\text { material }\end{array}$ & $\begin{array}{c}\text { During the } \\
\text { awareness-raising } \\
\text { phase }\end{array}$ & In the community & $\begin{array}{l}\text { Inform the community } \\
\text { about how to correctly } \\
\text { manage WCO }\end{array}$ & $\begin{array}{l}\text { Handing out pamphlets } \\
\text { in the community }\end{array}$ & $\begin{array}{l}\text { The estimated cost of } \\
100 \text { Brazilian reais }\end{array}$ \\
\hline Teachers & $\begin{array}{l}\text { Include EE in the annual } \\
\text { plan for the school } \\
\text { curriculum }\end{array}$ & $\begin{array}{l}\text { Throughout the entire } \\
\text { school year }\end{array}$ & $\begin{array}{l}\text { Classrooms, after } \\
\text { school, school } \\
\text { premises }\end{array}$ & $\begin{array}{l}\text { Raise awareness about the } \\
\text { impacts of WCO and the } \\
\text { need for correct collection } \\
\text { and destinations }\end{array}$ & $\begin{array}{l}\text { Multidisciplinary EE } \\
\text { activities aimed at WCO } \\
\text { collection involving the } \\
\text { community and students }\end{array}$ & $\begin{array}{c}\text { The estimated cost of } \\
20 \text { Brazilian reais per } \\
\text { piece of educational } \\
\text { material }\end{array}$ \\
\hline Students & $\begin{array}{l}\text { Systematically monitor the } \\
\text { WCO generated at home }\end{array}$ & Monthly & Residences & $\begin{array}{l}\text { Monitor the amount of } \\
\text { WCO generated at home }\end{array}$ & $\begin{array}{l}\text { A report with } \\
\text { information about and } \\
\text { monitoring of the actions } \\
\text { in their households }\end{array}$ & - \\
\hline PTA & $\begin{array}{l}\text { Systematically monitor the } \\
\text { WCO generated in their } \\
\text { community and collected } \\
\text { by the school }\end{array}$ & Monthly & $\begin{array}{l}\text { Community } \\
\text { households }\end{array}$ & $\begin{array}{l}\text { Monitor adherence of } \\
\text { generators and amount of } \\
\text { WCO collected }\end{array}$ & $\begin{array}{l}\text { Monitoring and reporting } \\
\text { the collected data }\end{array}$ & - \\
\hline Community & $\begin{array}{l}\text { Effective participation in } \\
\text { delivering WCO }\end{array}$ & Ongoing & School/VDPs & $\begin{array}{l}\text { Actively participate in the } \\
\text { project }\end{array}$ & $\begin{array}{l}\text { Separate PET plastic } \\
\text { bottles and deliver them } \\
\text { to the school/VDP }\end{array}$ & - \\
\hline
\end{tabular}

${ }^{1}$ The amounts correspond to the quote conducted in December 2017. NOTES: EE—environmental education 


\subsection{Discussion}

The research question for the present study was: "How can a public school in the RMPF of the state of Rio de Janeiro, Brazil, act as a voluntary delivery point and support the development of a reverse supply chain for waste cooking oil?" In order to answer that question, we developed an action plan based on the integration of actors and efforts. The local government, through the secretaries of education and environment and the water and sewer treatment company, could provide some incentives for school management, teachers, students, the PTA, and the community to foster acceptance of the idea of WCO collection and recycling.

At the same time, as a VDP, the school needs to be integrated into the WCO reverse supply chain, connecting household generators with collectors. One important issue is the logistics of this integration. Environmental education is an important tool for teaching the community how to appropriately store WCO that is of good quality and also to convince them to take WCO to the school's VDP.

Regarding the WCO reverse supply chain, the results show the importance of establishing contracts between commercial generators and collection cooperatives/companies, with price incentives for volume and quality, appropriate storage conditions, the frequency of generation, and avoiding exchange for cleaning products (soap) that don't meet environmental standards.

The collection cooperatives/companies should also use routing systems with enough vehicles that are managed by trained personnel, in order to minimize logistics costs. In addition, the biodiesel industry should adopt more proactive behavior, coordinating the chain and establishing a strong relationship with recycling cooperatives and companies, to ensure a continuous supply of WCO.

In addition, the local government should play a role in the WCO reverse supply chain, primarily: regulating the actors with incentives (tax) and controls; formalizing self-employed informal collectors by integrating them into existing cooperatives/associations; preventing soap production that does not follow environmental standards; maintaining the continuity of environmental education programs, along with WCO collection, in order to foster the development of more environmentally friendly citizens and reduce the cost of water and sewer treatment.

The results of the present study are in line with the literature review. Waste management related to WCO involves non-generation, reduction and recycling [23]. In order to accomplish this, the reverse supply chain needs to work well in terms of organization, cost efficiency and value generation [9], integration of small- and large-quantity generators [29], and adequate storage conditions [30]. Voluntary delivery points are strategic for collecting WCO from households (small-quantity generators) [11], without neglecting the importance of route planning to keep logistics costs down [32].

The idea of generating an action plan is also related to the National Solid Waste Policy, which demands a Municipal Plan of Integrated Solid Waste Management with shared responsibility among generators, collectors, recyclers and industry, and social inclusion of individual collectors in cooperatives and associations $[13,22,24,25]$.

However, since there are no specific regulations for WCO reverse logistics [7], environmental education in schools is an important strategy to compensate for that gap. It is important to insert this issue across school subjects and curricula $[42,45]$ Several other factors are also important: involvement of the community in school activities [51,52]; presenting information about the cost of collective selection programs and the convenience of VDPs [41]; highlighting biodiesel as the main product generated from WCO $[37,38]$. It is hoped that such programs will generate citizen awareness of ways to dispose of WCO appropriately [41,50].

\section{Conclusions}

The present study showed that the current structure of the WCO reverse supply chain in the RMPF is based on weak partnerships between generators and collector cooperatives and companies, and also showed lack of effective communication between the links in the chain. Other bottlenecks and requirements indicated by the participants were: lack of public awareness; a regional culture of WCO 
destinations being homemade soap production; the need to obtain a minimum volume for collection; competition among collectors; and quality specifications for WCO destined for biodiesel production.

In the present scenario, we evaluated the types of stakeholder participation and actions related to the selective collection, reverse logistics, and other actions regarding shared responsibility and environmental awareness. We concluded that the proper functioning of a WCO reverse supply chain depends on various factors. First, the population must be informed about the environmental damage caused by the improper disposal of this type of waste and about recycling possibilities. The reverse logistics of WCO also benefit from facilitated access to VDPs, incentives for formal contracts between cooperatives and commercial generators, optimization of collection routes, and specific incentive policies and legislation.

The development of reverse logistics is in the government's best interest. However, the actors that are part of the process are not given priority, and WCO collection programs and economic incentive programs (fiscal/tax) lack continuity. Furthermore, municipal selective collection programs established by the National Solid Waste Policy are mandatory, but local governments do not have information about or control of the destinations of all the WCO generated in their municipalities; they only control the volume processed by registered recycling cooperatives and companies.

The present analysis of the possibility of a municipal school operating as a VDP in a WCO reverse supply chain in the RMPF showed that VDP programs in schools cannot be one-offs, resulting in isolated actions such as rallies or events. These actions must be ongoing and part of the political-pedagogical program and school curriculum. Only in this way is it possible to implement the proposed action plan, as part of the environmental education program, in order to use the municipal school as a VDP.

It is important that students and the community actively participate in developing and implementing the WCO collection action plan. The study also pointed to a lack of public awareness regarding the damage caused by the improper disposal of WCO; lack of knowledge about the existence of VDPs; and criticism of discontinuity in collection and recycling initiatives.

One limitation of this study relates to the data collection phase. There was a paucity of literature about the actions of schools as VDPs and about WCO collection as a tool for environmental education. Similarly, there was a lack of a public database about WCO generation, collection and destinations. Additionally, the case study method doesn't permit generalization of results; further study is needed to support our conclusions.

Future studies should focus on the implementation of the action plan at the Washington Luiz Municipal School. It is hoped that the present investigation can guide other schools in developing similar action plans. Additionally, the authors suggest that this research is applied to other regions and that there be a more in-depth investigation about other actions that involve the participation of public schools in the management of other solid urban waste.

Funding: This research received no external funding

Conflicts of Interest: The authors declare no conflicts of interest.

\section{Appendix A. Questionnaire Applied to the Community in General}

1. What is your age?

2. What is your education?

( ) Elementary ( ) High school ( ) Higher education

3. How many people live in your house?

4. What is the range of monthly family income?

( ) less than 1 minimum wages (MW) ( ) 1 to $2 \mathrm{MW}$ ( ) 3 to $4 \mathrm{MW}$ ( ) over $4 \mathrm{MW}$

Do you receive a family grant from "Bolsa Família"? ( ) Yes ( ) No

5. Do you know what environmental education (EE) is?

( ) No ( ) Yes 
If so, what do you think EE means?

6. What are your daily actions to help preserve the environment?

7. What do you do with the WCO in your home?

( ) put it down the kitchen drain ( ) throw it away with the trash ( ) Donate it ( ) Make soap with it ( ) Sell its. If you donate it, to whom?

8. What do you think most people do with this oil?

9. Do you know about any public or private initiatives for the destination of the oil? ( ) No ( ) Yes. Which one?

10. How many liters of oil does your family consume monthly?

11. How many times is the oil is used before discarding?

12. Did you know that WCO can be recycled? ( ) No ( ) Yes. And where?

13. Do you know the damage caused by the improper disposal of WCO?

14. Would you use any product made with WCO as a raw material? ( ) Yes ( ) No

15. What is the main difficulty in keeping the WCO?

16. What is the main difficulty in taking the WCO to the collection points?

( ) Distance ( ) Time ( ) Lack of interest ( ) Other

\section{Appendix B. Questionnaire Applied to the Students of the Washington Luiz Municipal School}

1. How old are you?

2. What is your year of schooling?

3. Do you know what environmental education is? ( ) Yes ( ) No

4. What do you think environmental education means?

5. Have you ever participated in a WCO collection program at your school? ( ) Yes ( ) No

6. What would motivate you to participate?

7. Do you know the consequences of incorrect disposal of WCO in the environment?

8. What is the destination of WCO discarded in your home?

9. Do you know which destinations the WCO could have?

10. How important are environmental issues for you, on a scale of 0 to 10 , where 0 means very low and 10 means very high?

\section{Appendix C. Interview with Education Agents (Managers, Teachers and Support Staff) of the Washington Luiz Municipal School}

Interviewee's role and experience:

1. Does the school in which you work has actions in the environmental education area?

2. What is your commitment to environmental education in your school?

3. How often, per week, do you address environmental issues? ( ) Once ( ) Twice ( ) More than twice ( ) Never.

4. Do you find it difficult to work on environmental issues? ( ) Yes ( ) No

5. What do you think is missing from your school? () The teachers' commitment ( ) Commitment of the management of school ( ) Commitment of the technical-pedagogical team ( ) Interest of students ( ) Commitment of teachers, management and the technical-pedagogical team ( ) Lack of technical knowledge ( ) Lack of didactic resources ( ) Other.

6. Has the school elaborated its Political Pedagogical Project (PPP)? ( ) No ( ) Yes ( ) I do not know.

7. What environmental topics are addressed/worked on? (Mark all applicable items) () Public policy () Pollution ( ) Climate change ( ) Biomes/Ecosystems ( ) Basic sanitation ( ) Socioenvironmental sustainability ( ) Elections ( ) Water resources ( ) Social inequality ( ) Generation of work and income ( ) Associations / cooperatives ( ) Diseases ( ) Social inclusion/Social values ( ) Conservation ( ) Food ( ) Selective collection ( ) WCO disposal ( ) Solid waste ( ) 
Socioenvironmental responsibility ( ) Sustainable consumption ( ) Ethnic-racial relations ( ) Biodiversity ( ) Deforestation ( ) Environmental phenomena ( ) Quality of life ( ) Health in general ( ) Other.

8. In your opinion, what are the main difficulties and obstacles currently faced by the school in the development of activities/projects?

(Mark all applicable items) ( ) Absence of planning to guide the school ( ) Very infrequent meetings ( ) Lack of structure (rooms, physical space and equipment) ( ) Lack of teaching material ( ) Difficulty in mobilizing people and entities to collaborate with the school ( ) Members who are burdened with other professional activities ( ) Government political discontinuities ( ) Difficulty of conceptual understanding of the proposals ( ) Lack of teacher training ( ) Other.

9. How do you develop, in practice, the teaching of environmental education? (Mark all applicable items) ( ) In the curricular contents of my discipline(s) ( ) Multidisciplinary, involving more than one subject area in collective projects ( ) In individual research projects ( ) In collective research projects ( ) In actions of mobilization and social participation ( ) Other.

10. Mark the resources that are normally used to develop the actions in Question 9 above (Check all applicable items) ( ) Related texts ( ) Examples of local reality ( ) Relation of the problem with environmental, social and economic aspects ( ) Magazines and periodicals ( ) Internet, CDs, DVDs and television ( ) Playful material ( ) Political Pedagogical Project ( ) NCPs ( ) Textbook s( ) Teaching materials containing information about the environment () Bibliographic or scientific material on environmental issues ( ) Specific pedagogical material son environmental issues () Other.

11. Has the school developed, or is it developing, interdisciplinary project(s) around the issue of WCO? ( ) Yes ( ) No.

12. What is your level of acceptance of an action plan for environmental education with the school as a WCO collection point, on a scale of 0 to 10 , where 0 means totally against and 10 strongly in favor?

\section{Appendix D. Interview with People from the Municipal Secretariat for Environment and Sustainable Development (SMMADS)}

Interviewee's role and experience:

1. What is the functioning mechanism of the secretariat? Functional organization chart?

2. Does the municipality have a specific law for the collection of WCO?

3. How does the municipality inspect the disposal of WCO in commercial organizations?

4. Is there any initiative to foster collection by the government? If not, in your opinion, why not? If yes, which one?

5. Is there technical assistance or training for collectors and cooperatives?

6. What is the local infrastructure for storing collected oil?

7. Is there any kind of association between the secretariat and the cooperatives?

8. How are the cooperatives managed?

9. Who is responsible for collection at the registered donation points?

10. How is the collected oil commercialized?

11. How are the values defined?

12. Is there any environmental education program about the consequences of incorrect oil disposal? If yes, where? If not, what is the reason?

13. Who is responsible for transporting the raw material to the industry? Are freight costs included? How are they calculated?

14. Based on your experience, what are the strengths and weaknesses of the program?

15. How are schools included in this program? 
16. What is the incentive given for environmental education?

\section{Appendix E. Interview with WCO-Generating Agents in the Community}

Interviewee's role and experience:

1. What is the average monthly amount of vegetable oil used?

2. What is the average monthly amount of WCO discarded?

3. What is the process used in frying: pan, electric fryer, air-fryer?

4. Does the frying process affect the quality of the WCO?

5. How often is the oil reused?

6. What is the destination of the WCO?

7. Is there any government policy for WCO? What is it?

8. Is there any political or social incentive given by the government?

9. In what way is this oil collected?

10. How is the oil stored and transported?

11. Is this oil donated or sold?

12. If sold, please indicate the amount?

13. Is there any partnership with a public or private body? Which one?

14. What are the benefits of this process?

15. Has the consumption recently increased or decreased?

16. To what do you attribute this variation in consumption?

17. Does any specific factor affect consumption, such as concern about health, obesity and fitness wave?

18. What are the obstacles to the collection or final destination?

19. Based on your experience, is there potential for growth in the collection programs?

\section{Appendix F. Interview with Collector Cooperatives and Associations, NGOs and Companies (Some Questions Were Used with a VDP)}

Organization type:

Interviewee's role and experience:

Contact:

1. How many families/people are involved in WCO recycling projects?

2. Are there any political or social incentives given by the government?

3. What is the process for registration of collection points?

4. What kind of company can participate and what is the benefit?

5. What is the monthly amount collected?

6. Has collection recently has increased or decreased?

7. To what do you attribute this variation in the collection?

8. How is the WCO stored and transported?

9. How is the WCO collected?

10. Is the WCO is donated, bought or sold?

11. If bought or sold, could you tell us how much?

12. What is the destination of the WCO?

13. Is there any partnership with public or private bodies? Which one (s)?

14. Does the organization have any partnership with schools?

15. What are the obstacles in the collection or final destination?

16. Based on your experience, is there potential for growth in collection programs?

17. Is there any competition in the region in terms of supply and demand? 
18. Is there is any competition with other cooperatives or self-collectors? Which ones?

19. How would you rate the relationship among the collectors of WCO?

( )Cooperative ( ) Competitive ( ) Coopetition

20. What is the relationship between buyers and sellers?

( )Contract ( ) Spot market

21. What are the needs for improvement in the collection and destination process?

22. Do employees receive assistance? What kind?

23. What are the main difficulties in the reverse logistics of WCO?

24. Does the WCO have to be strained or filtered before the sale?

25. How is the processing done?

26. Are chemical reactants used?

27. Do employees use personal protective equipment?

28. How are R\&D projects, if any, financed?

29. Is there adequate infrastructure for transport?

30. Is the mode of transport suitable?

31. Is the number of vehicles sufficient to meet the demand?

32. Does the frequency meet the demand?

33. Is there adequate infrastructure for storage?

\section{Appendix G. Interview with the Biodiesel Company}

Organization type:

Interviewee's role and experience:

Contact:

The installed capacity of the company:

Production capacity used:

1. Is there any program or government policy for the production of biodiesel based on WCO?

2. Is there any certification for those who purchase WCO from local cooperatives?

3. Does the company receive inspection and health monitoring services?

4. Does the company reach its production potential?

5. Is there competition in the of the region in terms of WCO demand?

6. Who are the competitors in the use of WCO in the region?

7. How do you evaluate the relationship of WCO supply and demand?

8. How do you relate with WCO suppliers?

( ) Contract ( ) Spot market

9. Who are your key suppliers?

10. How much do you pay for a liter of WCO?

11. Is this value competitive for biodiesel?

12. In your opinion, what are the main problems of WCO collection?

13. What could be done to increase its efficiency?

14. Are there any technological restrictions on biodiesel production from WCO?

15. What is the yield of biodiesel from WCO?

16. What are the expectations to increase biodiesel production from WCO?

17. What are the main quality indexes tracked?

\section{References}

1. Lieder, M.; Rashid, A. Towards circular economy implementation: A comprehensive review in context of manufacturing industry. J. Clean. Prod. 2016, 115, 36-51. [CrossRef] 
2. Stahel, W.R. Circular economy: A new relationship with our goods and materials would save resources and energy and create local jobs, explains Walter, R. Stahel. Nature 2016, 531, 435. [CrossRef] [PubMed]

3. Hoornweg, D.; Bhada-tata, P. What a Waste: A Global Review of Solid Waste Management. In Urban Development Series Knowledge Papers; The World Bank: Washington, DC, USA, 2012.

4. Rathi, S. Alternative Approaches for Better Municipal Solid Waste Management in Mumbai, India. Waste Manag. 2005, 26, 1192-1200. [CrossRef] [PubMed]

5. Kalam, M.A.; Masjuki, H.H.; Jayed, M.H.; Liaquat, A.M. Emission and performance characteristics of an indirect ignition diesel engine fueled with waste cooking oil. Energy 2011, 36, 397-402. [CrossRef]

6. ABIOVE-Associação Brasileira das Indústrias de Óleos Vegetais. Available online: http:/ / www.abiove.org. br/ (accessed on 1 July 2016). (In Portuguese)

7. Brasil. Lei 12.305, de 02 de Agosto de 2010. Dispõe Sobre a Política Nacional de Resíduos Sólidos. Diário Oficial da República Federativa do Brasil: Brasília, 03 de Agosto 2010. Available online: http://www. planalto.gov.br/ccivil_03/_ato2007-2010/2010/lei/112305.htm (accessed on 1 July 2017). (In Portuguese)

8. Câmara Dos Deputados. Projetos de Lei n. 2.074, de 2007. Dispõe Sobre a Obrigação dos Postos de Gasolina, Hipermercados, Empresas Vendedoras ou Distribuidoras de Óleo de Cozinhas e Estabelecimentos Similares de Manter Estrutura Destinada a Coleta de óleo de Cozinha Usado e da Outras Providencias. Brasília. Available online: http:/ / www.camara.gov.br/sileg/Prop_Detalhe.asp?id=368364\&st=1 (accessed on 1 September 2016). (In Portuguese)

9. Pitta, O.S.R., Jr.; Neto, M.S.; Sacamano, J.B.; Lima, J.L.A. Reciclagem de óleo de cozinha usado: Uma contribuição para aumentar a produtividade do processo. In Proceedings of the International Workshop Advanced in Clear Production, "Key Elements for a Sustainable World: Energy, Water and Climate Change", São Paulo, Brazil, 22 May 2009. (In Portuguese)

10. Guabiroba, R.C.S.; D’Agosto, M.A.; Franca, L.S. Viability analysis of popular cooperatives in the participation of residual frying oil to biodiesel plants supply chain. J. Transp. Lit. 2014, 8, 164-186. [CrossRef]

11. Lago, S.M.S. Logística Reversa, Legislação e Sustentabilidade: Um Modelo de Coleta de óleo de Fritura Residual Como Matéria-Prima para Produção de Biodiesel. Ph.D. Thesis, Desenvolvimento Regional e Agronegócio. Universidade Estadual do Oeste do Paraná, Toledo, Paraná, 2013. (In Portuguese)

12. César, A.S.; Werderits, D.E.; Saraiva, G.L.O.; Guabiroba, R.C.S. The potential of waste cooking oil as supply for the Brazilian biodiesel chain. Renew. Sustain. Energy Rev. 2017, 72, 246-253. [CrossRef]

13. Leite, P.R. Logística Reversa: Meio Ambiente e Competitividade, 2nd ed.; Pearson Prentice Hall: São Paulo, Brazil, 2009; p. 240. (In Portuguese)

14. Disconzi, G.S. Coleta Seletiva do óleo Residual Doméstico: Desafios e Perspectivas para um Aproveitamento Socioambiental e Sustentável. Master's Thesis, Engenharia Ambiental-Universidade Federal de Santa Catarina, Santa Catarina, Brazil, 2014. (In Portuguese)

15. Zucatto, L.C.; Welle, I.; Silva, T.N. Cadeia reversa do óleo de cozinha: Coordenação, estrutura e aspectos relacionais. Rev. Admin. Empres. 2013, 55, 442-453. (In Portuguese) [CrossRef]

16. Ferreira, L.S. Cadeia Reversa do óleo Residual de Fritura na Região do Médio Paraíba Fluminense: Uma Proposta de Plano de Ação de Fomento a Educação Ambiental Tendo Uma Escola Municipal Como Ponto de Entrega Voluntária. Master's Thesis, Programa de Pós Graduação em Administração. Universidade Federal Fluminense, Volta Redonda, Rio de Janeiro, Brazil, 2017. (In Portuguese)

17. Araujo, V.K.W.S.A.; Hamacher, S.; Scavarda, F.F. Economic assessment of biodiesel production from waste frying oils. Bioresour. Technol. 2010, 101, 4415-4422. [CrossRef] [PubMed]

18. Brasil. Ministério da Educação. Propostas de Diretrizes da Educação Ambiental para o Ensino Formal-Resultado do II Encontro Nacional de Representantes de EA das Secretarias Estaduais e Municipais (capitais) de Educação-2001 Educação Ambiental-por um Brasil Sustentável. Available online: http:/ / www.mma.gov.br/educacao-ambiental/politica-de-educacao-ambiental/programa-nacional-deeducacao-ambiental (accessed on 1 December 2016). (In Portuguese)

19. Srivastava, A.K. Green supply chain management: A state-of-the-art literature review. Int. J. Manag. Rev. 2007, 9, 53-80. [CrossRef]

20. Tibben-Lembke, R.S.; Rogers, D.S. Differences between forward and reverse logistics in a retail environment. Supply Chain Management. Int. J. 2002, 7, 271-282. [CrossRef]

21. Staff, L.T. The 4 R's of Reverse Logistics. Logistics Today. 2005. Available online: http:/ / www.logisticstoday. com/displayStory.asp?sNO=7304 (accessed on 1 December 2015). 
22. Mota, J.C.; Almeida, M.M.; Alencar, V.C.; Curi, W.F. Características e impactos ambientais causados pelos Resíduos Sólidos: Uma visão conceitual. In Proceedings of the Congresso Internacional de Meio Ambiente Subterraneo, São Paulo, Brasil, 15-18 September 2009. (In Portuguese)

23. Thode Filho, S.; Machado, C.J.S.; Vilani, R.M.; Paiva, J.L.; Marues, M.R.C. A logística reversa e a Política Nacional de Resíduos Sólidos: Desafios para a realidade brasileira. Rev. Eletrôn. Gestão Educ. Technol. Ambient. 2015, 19, 529-538. (In Portuguese)

24. Demajorovic, J.; Besen, G.; Rathsam, A.A. Os desafios da gestão compartilhada de resíduos sólidos face à lógica do mercado. In Diálogos em Ambiente e Sociedade no Brasil; Jacobi, P., Ferreira, L., Eds.; Annpas, Annablume: São Paulo, Brazil, 2006. (In Portuguese)

25. CEMPRE-Compromisso empresarial para a reciclagem. Lixo Municipal: Manual de Gerenciamento Integrado; CEMPRE: São Paulo, Brazil, 2010. (In Portuguese)

26. Machado Filho, C.A.P.; Marino, M.; Conejero, M.A. Gestão estratégica em cooperativas agroindustriais. Caderno Pesquisas Admin. 2004, 11, 61-69. (In Portuguese)

27. Santos, J. A logística reversa como ferramenta para a sustentabilidade: Um estudo sobre a importância das cooperativas de reciclagem na gestão dos resíduos sólidos urbanos. Reuna 2012, 17, 81-96. (In Portuguese)

28. Wildner, L.B.A.; Hillig, C. Reciclagem de óleo comestível e fabricação de sabão como instrumentos de educação ambiental. Rev. Eletrôn. Gestão Educ. Technol. Ambient. 2012, 5, 813-824. (In Portuguese)

29. França, C.G.B.; Guarnieri, P.; Diniz, J.D.A.S. Logística reversa de óleos e gorduras residuais (OGRs) para a produção de biodiesel. In Proceedings of the Congresso Da Sociedade Brasileira De Economia, Administracao E Sociologia Rural, Maceió, Brazil, 14-17 August 2016. (In Portuguese)

30. Gonçalves, M.F.S.; Chaves, G.L.D. Perspectiva do Óleo Residual de Cozinha (ORC) no Brasil e suas Dimensões na Logística Reversa. Rev. Espacios 2014. Available online: http://www.revistaespacios. com/a14v35n08/14350816.html (accessed on 1 October 2018). (In Portuguese)

31. Loss, M. Análise de Viabilidade Econômica do Recolhimento de Resíduos de Óleo de Fritura. In Trabalho de Conclusão de Curso (Graduação em Engenharia Química); Universidade Federal do Rio Grande do Sul, Porto Alegre: Porto Alegre, Brazil, 2011. (In Portuguese)

32. Guabiroba, R.C.; Da, S.; D'agosto, M.D.A. O impacto do custo de coleta do ORF de fritura disperso em áreas urbanas no custo total de produção de biodiesel-estudo de caso. Transportes 2011, 19, 59-67. (In Portuguese) [CrossRef]

33. Franco, R.; Freire, M.; Almeida, M.F. Reaproveitamento do óleo vegetal utilizado em frituras para produção de sabão. In Proceedings of the Congresso De Pesquisa E Inovacao Da Rede Norte Nordeste De Educacao E Tecnologia, Belém, PA, USA, 2009. (In Portuguese)

34. Mello, V.M.; Oliveira, G.V.; Suarez, P.A.Z. Turning used frying oil into a new raw material to printing inks. J. Braz. Chem. Soc. 2013, 24, 314-319. [CrossRef]

35. Ocampo, D.; Aguirre, E.D.; Osorio, A.; Rios, L.A. Lacas y selladores para madera a partir de resinas alquílicas obtenidas de aceites de higuerilla, palma y usados de fritura. Informaciontecnológica 2014, 25, 157-164. [CrossRef]

36. Thode Filho, S.; Costa, A.P.S.; Rodrigues, I.; Semna, M.F.M.; Silva, E.R. Bioproducts Production from Vegetable Oil Residual: Candle, Chalkand Modelling of Mass. Electron. J. Manag. Educ. Environ. Technol. 2014, 18, 14-18.

37. Piloto-Rodriguez, R.; Melo, E.A.; Goyos-Pèrez, L.; Verhelst, S. Conversion of by-products from the vegetable oil industry into biodiesel and its use in internal combustion engines: A review. Braz. J. Chem. Eng. 2014, 31, 287-301. [CrossRef]

38. Talebian-Kiakalaieh, A.; Amin, N.A.S.; Zarei, A.; Noshadi, I. Transesterification of waste cooking oil by heteropoly acid (HPA) catalyst: Optimization and kinetic model. Appl. Energy 2013, 102, 283-292. [CrossRef]

39. Barbosa, G.N.; Pasqualetto, A. Aproveitamento do ORF de Fritura na Produção de Biodiesel. In Trabalho Conclusão de Curso (Graduação em Engenharia Ambiental); Universidade Católica de Góias: Goiânia, Brazil, 2007. (In Portuguese)

40. Delatorre, A.B.; Rodrigues, P.M.; Aguiar, C.J.; Andrade, V.V.V.; Aredes, A.; Perez, V.H. Produção de Biodiesel: Considerações sobre as Diferentes Matérias Primas e Rotas Tecnológicas de Processos. Perspectivas Online-Ciências. Biol. Saúde 2011, 1, 21-47. (In Portuguese)

41. Jacobi, P. Educação ambiental, cidadania e sustentabilidade. Cadernos de Pesquisa 2003, 118, $189-205$. (In Portuguese) [CrossRef] 
42. Brasil. Lei 9.795, de 27 de abril de 1999. Dispõe Sobre a Educação Ambiental, Institui a Política Nacional de Educação Ambiental e dá Outras Providências. Diário Oficial da República Federativa do Brasil: Brasília, 28 de abril 1999. Available online: http://www.planalto.gov.br/ccivil_03/Leis/L9795.htm (accessed on 1 January 2017). (In Portuguese)

43. Reigota, M. Educação Ambiental, 6th ed.; Brasiliense: São Paulo, Brazil, 2004. (In Portuguese)

44. Tristão, M. Tecendo os fios da educação ambiental: O subjetivo e o coletivo, o pensado e o vivido. Educ. Pesquisa 2005, 31, 251-264. (In Portuguese) [CrossRef]

45. Barbieri, J.C.; Silva, D. Desenvolvimento Sustentável e Educação Ambiental: Uma trajetória comum com muitos desafios. Rev. Admin. Mackenzie 2011, 12, 51-82. (In Portuguese) [CrossRef]

46. Gonçalves, M.F.S. Planejamento da Logística Reversa do óleo Residual de Fritura Para uma Destinação Ambientalmente Correta; Dissertação (Mestrado em Energia); Universidade Federal do Espírito Santo: Espírito Santo, Brazil, 2016. (In Portuguese)

47. Tescarollo, I.; Thomson, J.P., Jr.; Amancio, M.S.; Alves, T.F.T. Proposta para avaliação da qualidade de sabão ecológico produzido a partir do óleo vegetal residual. Rev. Eletrôn. Gestão Educ. Technol. Ambient. 2015, 19, 871-880. (In Portuguese)

48. Benassuly, M.S.; Murta, A.L.S. Política Pública para Produção de Biodiesel a partir da Coleta Seletiva do ORF de Fritura: Estudo de Caso do Programa de Reaproveitamento de Óleo Comestível do Estado do Rio de Janeiro. Sustain. Bus. 2015, 54, 1-28. (In Portuguese)

49. Caldeira, C.; Queirós, J.; Freire, F. Biodiesel from Waste Cooking Oils in Portugal: Alternative collection systems. Waste Biomass Valoriz. 2015, 6, 771-779. [CrossRef]

50. Segatto, F.B. Conhecendo as formas de descartes do óleo saturado de cozinha para verificar a educação ambiental na escola. Rev. Eletrôn. Gestão Educ. Technol. Ambient. 2013, 10, 2122-2129. (In Portuguese) [CrossRef]

51. Trindade, N.A.D. Consciência ambiental: Coleta seletiva e reciclagem no ambiente escolar. Encicl. Biosf. 2011, 7,1-15. (In Portuguese)

52. MMA-Ministério do Meio Ambiente. Os Diferentes Matizes da Educação Ambiental no Brasil: 1997-2007. Secretaria de Articulação Institucional e Cidadania Ambiental; Departamento de Educação Ambiental: Brasília, Brazil, 2008; p. 290. (In Portuguese)

53. Yin, R.K. Case Study Research: Design and Methods, 3rd ed.; Sage: Thousand Oaks, CA, USA, 2003.

54. IBGE Cidades Censo 2013. Available online: https:/ / cidades.ibge.gov.br/ (accessed on 1 August 2016).

55. PPP-Projeto Político Pedagógico-Colégio Municipal Washington Luiz Washington Luiz Municipal School, 2016. (In Portuguese)

56. Abdalla, M.M.; Oliveira, L.G.L.; Azevedo, C.E.F.; Gonzalez, R.K. Qualidade em Pesquisa Qualitativa Organizacional: Tipos de triangulação como alternativa metodológica. Admin. Ensino Pesquisa 2018, 19, 66-98. (In Portuguese) [CrossRef]

57. Governo Do Estado Do Rio De Janeiro-Secretaria de Estado do Ambiente (SEA) 2014. Available online: http:/ / www.rj.gov.br/web/sea (accessed on 1 February 2017). (In Portuguese)

58. APROBIO-Associação dos Produtores de Biodiesel do Brasil. Available online: http://aprobio.com.br/ legislacao-mercado/especificacao-do-biodiesel/ (accessed on 1 August 2016).

59. Avila Neto, C.A.; Stefenon, S.F.; de Oliveira, J.R.; Coelho, A.S.; Venção, A.T.; Klaar, A.C.R. Aplicação do 5W2H para criação do manual interno de segurança do trabalho. Rev. Espacios 2016, 37, 19. (In Portuguese)

(C) 2018 by the authors. Licensee MDPI, Basel, Switzerland. This article is an open access article distributed under the terms and conditions of the Creative Commons Attribution (CC BY) license (http://creativecommons.org/licenses/by/4.0/). 